\title{
KULTUR PESANTREN: RELASI KIAI, SANTRI, DAN KITAB KUNING
}

\author{
Nur Fatoni \\ IAIN Walisongo Semarang \\ Jl. Walisongo No. 3-5 Telp. (+62-24) 7604554 \\ E-mail: nurfatoni@yahoo.com \\ HP. +62-818455587
}

Abstract: This article describes the boarding school culture which focuses on the relation among Islamic scholar, students at Muslim school, and kitab kuning. The data colleting method which is used in this research are observation, interview and documentation. This article shows that the soul of Islamic boarding school is the Islamic scholar and the supporting factors are students and kitab kuning. This combination is inseparable. The Islamic scholar responds the modernity by teaching that holy books in some levels based on the students' ability.

Abstrak: Tulisan ini mencoba mendeskripsikan kultur pesantren dengan memfokuskan pada relasi antara kiai, santri dan kitab kuning. Kajian ini menggunakan observasi partisipan, wawancara, dan dokumentasi sebagai teknik pengumpul data. Artikel ini menunjukkan bahwa ruh pesantren adalah kiai. Komponen yang mendorong ruh pesantren menjadi hidup adalah kitab kuning dan santri. Ketiganya adalah merupakan satu kesatuan yang tidak dapat dipisahkan. Keunikan Pesantren APIK adalah adaptasi Kiai dalam merespon kemodernan. Pembelajaran kitab kuning diklasikalkan sesuai dengan taraf perkembangan santri. Demikian juga, pesantren ini diminati masyarakat karena materi kitab kuning yang diajarkan.

Kata Kunci: kitab kuning, kiai, relasi, pesantren, bandongan, sorogan.

\section{A. Pengantar}

Salah satu tradisi agung Indonesia adalah tradisi pengajaran Islam seperti yang muncul di pesantren. Alasan pokok munculnya pesantren adalah untuk mentransformasikan Islam tradisional, sebagaimana terdapat dalam kitab kuning yang ditulis berabad-abad yang lalu (van Bruinessen, 1994: 17). 
Pandangan antropologi pesantren terhadap kitab kuning adalah menganggap ilmu yang ada pada kitab kuning sebagai sesuatu yang bulat, ut uh tidak dapat ditambah dan dikurangi, dan hanya bisa diperjelas dan dirumuskan kembali. Ciri utama dalam pendidikan pesantren adalah sikap hormat, ta' $z \bar{i} m$ dan kepatuhan mutlak pada kiai. Nilai tersebut sangat dikedepankan, yang sering lebih terlihat dibandingkan pendidikan intelektualnya.

Pondok pesantren salaf tua yang masih eksis sampai sekarang di antaranya Pondok Pesantren APIK Kaliwungu. Ia memiliki 700-an santri dan terletak di jantung kota Kaliwungu. Ia masih mempertahankan tradisi salaf dengan meneguhkan elemen lembaga pesantren dan peranan kiai kharismatik. Di sisi lain, ia mentransformasi sistem pendidikannya dengan sistem klasikal, bahkan memasukkan "Wajar Dikdas" dalam kegiatan pendidikan pesantren.

Fenomena ini menarik bagi penulis untuk melihat dari sisi cara pandang pesantren terhadap eksistensi kitab kuning sebagai sumber ilmu dan kiai sebagai agen ilmu tradisional. Tulisan ini didasarkan pada penelitian lapangan di Ponpes Apik Kaliwungu, dengan melakukan observasi, dokumentasi, dan wawancara. Penelitian ini dimaksudkan sebagai uji keberlangsungan relasi kiai, santri, dan kitab kuning yang pernah dilakukan oleh peneliti terdahulu pada tahun 1970an oleh Dhofier, 1980-an oleh Steenbrink dan 1990-an oleh van Bruinessen. Jika mereka mengambil lokasi yang luas dan melibatkan banyak pesantren, penulis memfokuskan pada satu pesantren.

\section{B. Sistem dan Tradisi Pendidikan Pesantren}

Dalam catatan Steenbrink, model pendidikan pesantren telah ada pada masa kolonial Belanda. Hanya saja, pemerintah Belanda tidak menganggapnya penting model tersebut untuk dimasukkan dalam statistik pendidikan (Steenbrink, 1986: 10-11) Data tentang model pendidikan pesantren bisa dilacak melalui tulisan dan laporan paran penulis Belanda seperti Hurgronje. Menurutnya, model pendidikan keagamaan yang paling sederhana adalah pengajaran al-Qur' an. Pendidikan lanjut annya adalah pengajaran kitab. Ada perbedaan pengajaran al-Qur'an dan kitab, yaitu: a) santri umumnya tinggal di asrama yang disebut pesantren, b) mata pelajaran yang diajarkan lebih banyak dibandingkan dengan pengajaran al-Qur'an, dan selalu dimulai dengan pelajaran Bahasa Arab, dan c) pendidikan diberikan secara kelompok dan individual (Steenbrink, 1986: 12).

Tingkat pertama pada pengajian kitab adalah mempelajari Bahasa Arab yang tersusun dalam uraian pendek, yang berbentuk sajak. Santri membaca dan 
menghafal teks Arab, kemudian isinya dijelaskan kata demi kata oleh ustadz atau kiai.

Pada pesantren yang lebih besar, pengajaran bahasa ini diberikan juga oleh guru bantu (ustadz), yaitu para murid tingkat lanjutan yang mendapat kepercayaan mengajar dari kiai. Meskipun pengajaran Bahasa Arab tidak secara langsung menyangkut masalah agama. Namun, suasana pesantren dijiwai pengajaran Arab dan al-Qur'an. Hal ini membuat pengajaran Bahasa Arab dianggap sebagai pengajaran agama. Waktu yang dibutuhkan untuk belajar Bahasa Arab (naḥwu șarāf) bervariasi dari enam bulan sampai enam tahun tergant ung dari kiai masing-masing dan bakat murid (Steenbrink, 1986: 13).

Setelah pengajaran bahasa selesai, para santri melanjutkan pelajaran agama yang sebenarnya, yang meliputi fiqh, tawhid dan tafsir al-Qur'an. Setelah lulus pelajaran pokok agama tersebut santri bisa melanjutkan belajar mata kuliah sampingan seperti Taṣawuf, Ḥadīts, Ḥisāb atau Falāq, yang semuanya tergantung pada keahlian atau perhatian kiai (Steenbrink, 1986: 14).

Model pembelajaran pesantren dilaksanakan secara individual maupun berkelompok dalam satu halaqah (lingkaran). Dalam sistem berkelompok, guru membacakan teks baris demi baris, menerjemahkan dan kalau dipandang perlu, memberikan penjelasan. Dengan cara tersebut, santri dapat mempelajari karya yang luas selama beberapa tahun, sebelum dapat mengerti seluruhnya. Lamanya waktu yang dipergunakan juga dapat disebabkan karena kiai membaca beberapa macam kitab yang dikuasainya sekaligus. Pelajaran berlangsung sepanjang tahun, dan hanya diselingi libur sekitar bulan mawlid dan Ramadhan selama sebulan atau lebih.

Santri baru tidak selalu terikat dengan tahun ajaran tertentu. Mereka boleh mulai kapan saja dikehendaki. Pada waktu permulaan, mereka ditolong oleh santri lama yang sudah lebih dahulu membaca dan memahami satu kitab selama beberapa bulan hingga mereka dapat berdiri sendiri. Kalau satu kitab tidak begitu besar, santri dapat mengikuti pelajaran beberapa kali sampai dapat memahami seluruh isi kitab.

Sebelum kitab-kitab cetakan bisa ditemukan dengan mudah, para santri diharuskan menyalin sendiri teks arab tersebut, tetapi dia selalu memberikan ruangan untuk ditulisi terjemahan maupun komentar, di pinggir tiap-tiap baris dari isi kitab tersebut. Santri yang mengikuti pengajian kitab kebanyakan meninggalkan rumah orangtuanya dan menetap pada salah satu pesantren. Pada umumnya, pesantren terletak di pinggiran kota atau desa yang agak jauh dari kota. Ia merupakan satu lingkungan yang khusus dan terpisah dari pemukiman lainnya. 
Lingkungan pesantren pada umumnya terdiri dari rumah kiai. Sebuah tempat peribadatan yang juga berfungsi sebagai tempat pendidikan (disebut masjid kalau digunakan untuk shalat Jumat, kalau tidak disebut dengan langgar atau surau. Rumah pondokan sendiri oleh para santri dari bambu atau kayu. Selain itu, ada sebuah atau lebih ruangan untuk memasak, kolam, atau ruangan untuk mandi atau berwudlu.

Pada pesantren yang lebih besar jumlah bangunan dalam lingkungan pesantren juga banyak sehingga merupakan desa tersendiri. Kebanyakan santri menetap di pesantren sepanjang hari, dan hanya meninggalkannya kalau ada keperluan tertentu seperti berbelanja, mencari nafkah dengan bekerja pada orang kaya yang membutuhkan dan keperluan lainnya.

Untuk meresapkan jiwa keislaman, pesantren tidak hanya dihormati sebagai tempat belajar, tetapi lebih ditekankan sebagai tempat tinggal yang seluruhnya dipenuhi dan diresapi dengan nilai-nilai agama. Tidak ada tempat lain di mana shalat didirikan dengan taat seperti di sana. Pada siang hari, orang dapat mendengar para santri membaca al-Qur'an dengan lagu yang indah, memperbaiki bacaan dengan tajwìd yang benar, atau sekadar mengharapkan pahala. Pada malam hari juga dapat dijumpai suasana orang membaca al-Qur'an melagukan kalam Ilahi, dan mendirikan shalat di tengah keheningan malam.

Hubungan antara santri dan kiai pada umumnya merupakan hubungan ketaatan tanpa batas, demikian pula kepada para "guru bantu". Akan tetapi, hubungan antar santri tidak tergantung dan dibatasi tinggi rendahnya stat us orang tua santri. Kehidupan sehari-hari dalam pesantren hampir seluruhnya diatur oleh santri sendiri. Kiai tidak terlibat langsung dalam kehidupan santri. Dia hanya mengajar membaca kitab, menjadi imām dan khatīb shalat Jumat, menghibur kalau ada orang sakit yang datang kepadanya sambil mencoba menasehati dan mengobati dengan doa-doa. Peraturan sehari-hari di pesantren seluruhnya diurus santri dan keterlibatan kiai terbatas pada pengawasan yang diam. Sesudah mendapat persetujuan dari kiai, santri memilih seorang lurah pondok yang akan bertanggung jawab pada kehidupan bersama para santri. Bersama kiai, lurah pondok menyusun peraturan untuk persoalan-persoalan praktis, yang pelaksanaannya diserahkan pada lurah pondok (Wawancara dengan Pengurus, 12 Agustus 2009).

\section{Pesantren APIK Kaliwungu: Sebuah Sketsa}

Pondok Pesantren APIK berada di sebelah utara masjid besar al-Muttaqin Kaliwungu. Letaknya berdampingan (dekat) dengan pemukiman penduduk dan keramaian kota Kaliwungu. Ia memiliki jumlah santri pada tahun 2009 
sebanyak 700 anak, dilengkapi dengan fasilitas asrama sebanyak 129 kamar untuk santri dan 4 kamar untuk pengurus. Kamar mandi 12 unit, WC 10 unit. Jumlah pengurus 33 anak yang terbagi dalam dua strata, pondok dan komplek (Dokumentasi Pesantren, 2009).

Pondok Pesantren Apik Kaliwungu berdiri di atas tanah waqaf K.H. Irfan. Ia didirikan pada awal abad 20 pada masa kolonial Belanda, tepatnya tanggal 12 Dzulhijjah 1338 H/12 Februari 1919 M. Bangunan Pondok dibangun dengan biaya 75 sen, yang 75 persen berasal dari keluarga pendiri, yaitu H. Abdurrosyid (kakak), dan sumbangan masyarakat Kaliwungu 25 persen.

Sejak awal, penataan organisasi pondok pesantren telah menggunakan format baku, yaitu ada pengasuh sebagai pembimbing santri dan lurah pondok yang dibantu dengan segenap pengurus sebagai pelaksana dan penanggung jawab kegiatan pendidikan dan rumah tangga pesantren. Lurah Pondok pesantren Apik Kaliwungu yang pertama adalah Ru'yat (keponakan pendiri), lalu dibantu oleh Usman Abdurrosyid (keponakan). Beberapa tahun kemudian, Ru'yat diganti oleh Idris dari Kempek, Cirebon (Wawancara dengan Kiai, 19 Agust us 2009).

K.H. Irfan mengasuh pondok selama 10 tahun sebelum ia wafat. Hampir bersamaan dengan peristiwa itu K.H. Idris selaku lurah pondok juga pindah ke Pondok Pesantren Tebuireng, Jombang. Pengasuh pengganti dipercayakan kepada K.H. Ahmat Ru'yat bin Abdullah bin Musa dan lurah pondok dipercayakan kepada K.H. Abdullah bin Idris bin Musa. Pada masa inilah, perkembangan jumlah santri bertambah banyak. Pada masa itu pula, dibangun lagi beberapa kompleks (asrama hunian santri). Pengasuh memberikan pengajian kepada santri dengan cara bandongan. Kitab yang ia baca adalah kitab-kitab dasar sampai Ihyā̄' 'Ulūm al-Dīn, Tafsīr Bayḍāwì, Fatḥ al-Wahhāb, Șaḥihh Bukhārì, dan Șaḥị̣ Muslim. Pengasuh terkenal sebagai kiai yang 'ālim dan wirā ${ }^{\prime} \bar{i}(z u h d)$. Ia tidak memiliki kegiatan di luar pesantren. Kegiatan kesehariannya diisi dengan mengaji untuk santri dan beribadah (dokumentasi Pesantren, dikutip 22 Agustus 2009).

Pada tahun 1968, K.H. Ru'yat meninggal dan pengasuh pondok diserahkan kepada putra pendiri, yaitu K.H. Khumaidullah Irfan. Selama ia memimpin pondok, lurah pondok dipercayakan kepada Ustadz Dimyati Ro'is (pendiri Pondok Pesantren al-Fadlu wal Fadilah, Kaliwungu). Prestasi lurah pondok adalah menambah sistem klasikal pada pengajaran pondok. Ia menata kelas menjadi kelas SP (sifir atau persiapan), Tsanawiyah dua tahun dan Aliyah enam tahun disesuaikan dengan sistem pendidikan yang ada di bawah Depag pada 
waktu itu. K.H. Khumaidullah meninggal pada tahun 1985. Pengasuh pondok dipercayakan kepada putranya K.H. Muhammad Imron dan dibantu adiknya K.H. M. Sholahuddin Khumaidullah.

\section{Tradisi Pembelajaran \& Atmosfir Pesantren APIK Ka- LIWUNGU}

Model pengajaran Pondok pesantren ini telah mengenal penjadwalan dan penjenjangan pendidikan. Kegiatan pendidikan-nya fokus pada tafaqquh fi aldin (memperdalam ilmu, penghayatan dan amaliah agama). Penggabungan antara aspek kognitif berupa penalaran hasil karya 'ulama', klasik dalam Kitab Kuning, aspek afektif berupa penghayatan makna hidup mandiri dan dinamis, dan aspek psikomotorik berupa amaliah agama dalam bentuk kegiatan ibadah.

Berikut ini kegiatan santri dari bangun tidur sampai tidur lagi. Jam 03.30 shalat tahajjut, 03.50 (menyesuaikan dengan jadwal shalat subuh yang berlaku) jemaah shalat Subuh, ba'da shalat Subuh melaksanakan sorogan (santri membaca kitab/pelajaran di depan guru) untuk santri SP (kelas persiapan) I dan 2. Sementara itu, pada 06.00-07.00 bandongan (guru membaca kitāb murid mendengar dan menulis makna katanya). Pada jam 07.30-11.30 sekolah di madrasah Salafiyah Miftakhul Hidayah P.P. Apik, dilanjutkan dengan jemaah shalat Duhur. 12.30 - 13.00 ngaji Bandongan. Santri bebas memilih kitab dan ustadz yang mereka sukai.

Setelah jemaah shalat Asar 16.30-17.30 santri mengikuti ngaji wajib. Semua santri ngaji langsung dengan pengasuh. Setelah jemaah shalat maghrib 18.15-19.30 mengaji al-Qur'an. Khusus pada hari Selasa dan Jumat pada jam tersebut dilaksanakan istighatsah (membaca nama-nama Allah dan doa dengan rangkaian tertentu). Setelah jemaah shalat Isya' 20.00-22.00 musyawarah (kegiatan pembahasan pelajaran madrasah). Khusus hari Jumat pada jam tersebut santri melaksanakan jam 'iyah sughra yang diisi dengan kegiatan latihan pidato dan membaca kitab al-Barzanjī. Khusus pada hari Jumat Kliwon acara ditambah dengan istighatsah dan mawiḍah khasanah dari pengasuh. 22.0023.00 bandongan bebas (dokumen Pesantren, dikutip 15 Agustus 2009).

Kitab yang dibaca dalam bandongan baik adalah 1) al-Bajuri (fiqh) diasuh oleh Ustadz Mustakim pada ba'da musyawarah, 2) Kifāyat al-Akhyār (fiqh) diasuh oleh Ustadz Waghfir Kholison pada ba'da musyawarah, 3) Minhāj alQawìm (fiqh) diasuh oleh Ustadz Abdunnafi' pada ba 'da Așar, 4. Safĩnat alNajāh (fiqh) diasuh Ustadz Subkhan Mashudi pada musyawarah, 5) Iḥyā' 'Ulūm al-Din (tasawuf) Ustadz Fadlullah pada ba 'da musyawarah, 6) Badi'udz Dzuhur 
(sejarah) diasuh oleh Ustadz Nur Dhuha pada ba'da musyawarah, 7) Syarah alHikam (tasawuf) diasuh oleh ustadz Mansur Amin pada ba'da musyawarah, 9) Mihāj al-Saniyah (Tasawuf) diasuh oleh ustadz Mustakim Hakim pada Jumat jam 09.00 WIS; 10) Manāqib Syaykh Abd al-Qādir al-Jilānì (sejarah) diasuh oleh ustadz Mustakim hakim pada ba'da dhuhur, 10) Taysīr al-Khalaq (tasawuf) diasuh oleh ustadz A.Tajuddin pada ba'da musyawarah, 11) Al-Diba'i (sejarah) diasuh oleh ustadz Tajuddin pada ba'da musyawarah, 12) Syarakh Mutammimah (bahasa) diasuh oleh ustdaz Waghfir Khalisan pada ba'da Ashar; dan 13) Nașaih al-'Ibād (Tasawuf) diasuh oleh ustadz Fahruddin pada ba'da musyawarah (dokumen Pesantren, dikutip 12 Agustus 2009).

Kurikulum pondok pesantren Apik Kaliwungu diaplikasikan dalam penyusunan mata pelajaran berupa kajian kitab dan penjenjangan pada Madrasah Diniyah menjadi Tingkat Persiapan, Tingkat Tsanawiyah, dan Tingkat Aliyah. Jika pada masa lurah pondok Ustadz Dimyati Rois jenjang Tsanawiyah ada yang enam tahun, maka sekarang yang dilaksanakan adalah penjenjangan seperti pada madrasah departemen agama, tingkat SP (setingkat dengan dasar), tingkat tsanawiyah (setingkat menengah pertama) dan tingkat aliyah (setingkat menengah atas). Kiai memiliki peran penting dalam memberikan arahan kepada lurah pondok dan pengurus dalam melaksanakan kurikulum tersebut, meskipun ia tidak turun tangan langsung. Pengasuh menentukan kitab dan sumber apa saja yang bisa diakses oleh santri selama melaksanakan pendidikan di Pondok Pesantren APIK Kaliwungu. Pengasuh menyadari betul adanya tingkat perbedaan kemampuan mencerna sumber sebagai sumber ilmu dan amal. Pengasuh memiliki koleksi kitab-kitab modern seperti karya Muhammad Abduh, Rasyid Ridha maupun buku-buku modern karya Iqbal dan Fazlurrahman. Akan tetapi, kitab dan buku tersebut dilarang untuk dibaca santri.

Santri dibatasi dalam kerangka visi pesantren, "Menghidupkan dan menjaga warisan ajaran salaf al-ṣālih". Sumber bacaan dan kitab standard di madrasah diniyah relatif sama sejak pesantren ini didirikan. Adapun keterangan nama-nama kitab yang digunakan pada semua jenjang adalah sebagai berikut:

1. Tingkat SP kelas 1 adalah Qirā'ati, Juz.5-6, Sulām al-Mubtadi', Fashalatan, 'Aqīidat al-Awwām, Tanwīr al-Qāri, Sya'iran, Kamus Bahasa Arab, Naḍam 'alāla dan Mabādi' al-Fiqhiyyah.

2. Tingkat SP kelas 2 adalah al-Jurümiyah, Safīnah Șalāt, al-Kharìdat alBahiyyah, Hidāyat al-Ṣibyān, al-Akhlāq li al-Banīn Juz.1-2, al-Amtsilat Tașrifiyyah, Tanbīh al-Muta 'alim, al-Qur'ān, Mukhtașar Jiddan.

3. Tingkat Tsanawiyah kelas 1 adalah al-Jurūmiyah,, al-'Awāmil al-Jurjānì, Safīnah al-Najāh, al-Amtsilah al-Taṣrifiyyah, Khulāṣah Nur al-Yaqịn, Qawā'id 
Khath al-'Arābī, Qawā'id al-'I'lāl, al-Jawāhirul Kalamiyah, Wașāyā, Tukhfat alAțfāl, dan Asymāwì.

4. Tingkat Tsanawiyah kelas 2 adalah al-Imrity, Biafụala, Naḍam alMaqșūd, al-Jurūmiyyah, Ta 'Tim al-Muta'allim, Qawā'id al-I'rāb, al-Dār al-Farīd, al-Amtsilah al-Tașrifiyyah, al-Arba'īn Nawāwiyyah, Fatḥ Rabbi al-Bariyah.

5. Tingkat tsanawiyah kelas 3 adalah Alfiyah ibn Mālik, Fatḥ al-Qārib, Bulūgh al-Marām, al-Bayquniyyah, al-Waraqāt, Tijsni al-Dāri, Ibnu 'Āqil.

6. Tingkat Aliyah kelas 1 adalah Alfiyah ibn 'Āqil, Fat al-Mu'īn, Iddat alFarīụ, Bulūgh al-Marām, Tașil al-Ṭarīqah, Kifayat al-Awwām, Minkhat alMughïts, Dakhlan Alfiyah.

7. Tingkat Aliyah kelas 2 al-Jawāhir al-maknūn, al-Sulam al-Munawwaraq, Fat al-Mu 'in, 'Umm al-Barāhin, al-Farā'id al-Bahiyyah, Naḍm al- 'Arūḍ, Lubb al-Ușūl, Khaliayt al-Lubb al-Mașun.

8. Tingkat Aliyah kelas 3. adalah al-Muḥallā juz. 1-4, 'Uqud al-Jamānī, Tafsìr al-Jalālayn, al-Muwatța', Jamī' al-Jawāmī', Minhāj al 'Ā bidin (dokumen Pesantren, dikutip 19 Agustus 2009).

\section{Hubungan Segitiga: Kiai, Santri, dan Kitab Kuning di Pesantren APIK}

Pondok pesantren menurut Dhofier memiliki lima pilar/elemen, yaitu santri, kiai, pengajaran kitab kuning (klasik), masjid dan pondok. Santri dan kiai adalah aktor dalam kehidupan pesantren, sedangkan masjid dan pondok adalah fasilitas standar yang senantiasa ada untuk mencirikan keberadaan sebuah pondok pesantren dan kitab kuning menjadi alat transformasi tradisi dan keilmuan Islam klasik yang senantiasa dipertahankan di Pondok pesantren. Pondok Pesantren APIK Kaliwungu adalah salah satu pesantren klasik/salaf yang masih utuh menjaga elemen tersebut, bahkan tidak tertarik mengembangkan diri menjadi pesantren dengan sekolah umum, seperti beberapa pesantren salaf lainnya.

Pengasuh pesantren biasanya adalah pendiri atau orang yang mendapat mandat untuk meneruskan tugas tarbiyah (pendidikan dan pengasuhan) di pesantren. Ia adalah seorang 'ulamā', yang diyakini oleh kalangan pesantren mumpuni dari sisi ilmu agama, baik ilmu ḍahïr maupun ilmu bațin. Ia memiliki posisi paling esensial dalam pesantren. Perkembangan pesantren bergantung pada kemampuan pribadi kiai yang mengasuh. Para kiai beranggapan bahwa suatu pesantren adalah kerajaan kecil, di mana kiai adalah sumber mutlak dari kekuasaan dan kewenangan dalam kehidupan dan lingkungan pesantren. Para 
kiai umumnya termasuk bagian dari kelompok elite dalam struktur sosial, politik, dan ekonomi. Para kiai adalah orang-orang yang memiliki kekuatan politik. Kemampuan dan kegiatan mengajarkan ilmu agama membuahkan pengaruh yang melampaui batas-batas desa di mana pesantren mereka berada.

Kerangka gambaran kiai pengasuh pesantren yang dikemukakan Dhofier di at as tampak implementasinya di pondok pesantren Apik Kaliwungu, meskipun ada jeda waktu yang lama antara penelitian Dhofier yang dilakukan pada 1975 dan penelitian ini, 2009. Kiai pengasuh Pondok Pesantren Apik memiliki kharisma yang agung di mata masyarakat dan santri. Ia senantiasa tampil dan menempatkan diri secara tepat, seolah ada "protokoler" yang mengat urnya. Dalam berpakaian misalnya, ia senantiasa menjaga penampilan khasnya sarung kualitas bagus, baju lengan panjang dan lebih sering mengenakan jas jika bepergian, peci hitam, dan sorban. Pakaian tersebut yang senantiasa terlihat jika ia tampak di luar rumah. Pakaian tersebut yang menampakkannya sebagai sosok yang kharismatik dan bersahaja. Dalam bertutur kata, sangat sopan dan menghormati tamu. Ia juga termasuk elite politik di kabupaten Kendal (Wawancara, 2 Agustus 2009).

Dalam hal manajemen pesantren, kiai tidak banyak turun tangan dalam mengelola pondok. Peran Kiai adalah lebih bersifat di balik layar. Sebenarnya, manajemen dan pengendalian pesantren ada di tangannya. Pintu masuk dan keluar pesantren bagi santri dan masyarakat adalah Kiai Pengasuh. Santri masuk (baru) dan keluar (lulus) harus seizin pengasuh. Pengaturan yang diterapkan di Pesantren adalah atas restu dan izin kiai. Kegiatan pengajian dan pengajaran juga atas restu dan izin kiai. Ustadz-ustadz yang diperkenankan mengajar diangkat dan diberhentikan oleh kiai. Penentuan besaran pembayaran dan iuran pondok juga atas restu dan izin kiai. Peran besar kiai ini sangat mewarnai kehidupan pengajaran dan kehidupan di Pesantren.

Dalam hal memberi pengajian kepada santri, kiai memberikan dalam bentuk bandongan dan masal. Semua santri dalam jenjang tertentu wajib ikut pengajian. Ia mengaji kitab Tafsìr Munìr dan Fatḥ al-Wahhāb bergantian dalam satu waktu. Pengajaran yang dilaksanakan di Madrasah Diniyah dan pengajian rutin lainnya diampu oleh para ustadz yang ditunjuk. Mereka adalah badal (pengganti/wakil) kiai. Mereka adalah orang-orang yang pernah mengaji kitab dengan kiai. Kitab yang diajarkan ustadz adalah kitab yang pernah ia ngaji dengan kiai. Ada sanad (silsilah/mata rantai) antara kiai dengan ustadz. Persoalan sanad ini menjadi jaminan kualitas seorang ustadz. Kiai bisa memilih ustadz mana yang dianggap mampu. Sanad tidak bisa diganti dengan sekadar 
kemampuan menerjemah kitab karena sanad juga menjadi matarantai ilmu yang diyakini memiliki nilai keberkahan.

Peran Kiai yang digambarkan sebagai raja kecil adalah keniscayaan dari sistem yang dibangun dalam pesantren. Kiai memiliki otoritas tunggal dan veto. Keputusan apapun yang diput uskan oleh pengurus bisa ditolak jika kiai tidak berkenan. Ada komunikasi unik antara kiai dengan lurah pondok. Lurah pondok dipilih langsung oleh kiai karena ia adalah kepercayaan kiai. Lurah pondok wajib menegakkan dan menjaga sistem yang dibangun kiai (Wawancara dengan lurah pondok, 12 Agustus 2009).

Santri yang tinggal di pesantren adalah penuntut ilmu yang siap ditempa menjadi ahli ilmu agama ( $t a f a q q u h$ fĩ al-din). Santri ada dua, yaitu santri mukim yang tinggal di asrama pesantren dan santri kalong yang tinggal di rumah masing-masing dan ke pondok pada saat mengaji. Di Pondok Pesantren APIK hanya ada santri mukìm (tinggal). Para santri menetap di pesantren memiliki banyak motivasi, di antaranya: a) ingin mempelajari kitab-kitab lain yang membahas Islam secara lebih mendalam di bawah bimbingan langsung kiai pengasuh pesantren, b) ia ingin memperoleh pengalaman kehidupan pesantren, baik dalam bidang pengajaran, keorganisasian, maupun hubungan dengan pesantren-pesantren terkenal; dan, c) ia ingin memusatkan studinya di pesantren tanpa disibukkan oleh kewajiban sehari-hari di rumah keluarganya. (Wawancara, 2 Agustus 2009).

Santri datang ke pesantren APIK memiliki sebab-sebab khusus, di samping motivasi umum di atas. Mereka umumnya datang karena mendapat rekomendasi dari para alumni pondok APIK. Hanya beberapa santri saja yang datang ke pondok APIK tanpa informasi dan rekomendasi dari alumni. Motivasi mereka adalah menyelamatkan diri dari gangguan lingkungan yang kurang baik di lingkungannya. Hal ini karena meratanya degradasi moral di masyarakat. Pesantren diyakini oleh orangtua dan santri mampu membentengi mereka dari pengaruh degradasi moral tersebut. Dari data yang ada, umur santri yang masuk cenderung ada peningkatan pada usia lulus sekolah dasar. Sekarang (tahun 2008-2009) mayoritas santri baru adalah lulusan SD/MI. Alasan orangtua memasukkan anaknya ke pondok pada usia sedini mungkin karena kekhawatiran tercemar degradasi moral. Ada rasa aman bagi orangtua, jika anaknya telah betah tinggal di pondok pesantren.

Kiai memahami betul motivasi tersebut. Ada proteksi kuat dari kiai untuk keamanan santri. Ada peraturan yang dilanggengkan sejak masa pengasuh K.H. Khumaidullah, yaitu: a) Santri dilarang melihat televisi dan mendengarkan radio, b) Santri dilarang keluar pondok selama kegiatan ngaji dan lainnya ber- 
langsung, c) Santri dilarang membaca koran dan buku-buku yang dilarang oleh pengasuh, d) Santri wajib mentaati tata tertib, dan e) Santri wajib melaksanakan riyāḍah (latihan batin) dengan cara beribadah kepada Allah dengan khusyü‘.

Peraturan tersebut tetap dilaksanakan, meskipun terasa berat. Larangan melihat televisi dan mendengarkan radio adalah paling berat dirasa. Santri kadang-kadang mencuri, walaupun harus siap di-ta'zïr kalau ketahuan. Mereka melaksanakan dan mengindahkan peraturan serta arahan kiai karena mereka yakin akan membawa barokah. Mencari "barokah" inilah yang menjadi kekuatan santri untuk melaksanakan perintah kiai.

Ada keunikan tatkala santri berinteraksi dengan kiai. Sopan santun santri sangat dijaga. Santri menunduk (tidak menatap muka kiai) dan tangannya tersipu jika bertemu atau berbicara dengan kiai. Jalan menggunakan lut ut saat masuk ke kediaman (dalem) kiai. Selalu berkata dan berpikir positif tentang kiainya. Berbicara santun dan seperlunya ketika merespons perkataan kiai, baik saat mengaji maupun di luar pengajian. Sami 'nā wa ata 'nā, atau sendiko dawuh dengan segala instruksi kiai. Hal-hal yang mereka lakukan pada kiai juga dilakukan pada keluarga kiai.

Kitab klasik yang digunakan oleh pondok pesantren adalah bermadzhab Syafí 'iyah. Tujuan pengajaran tersebut adalah untuk mendidik calon-calon 'ulamā' yang setia pada paham Islam Tradisional. Bagi santri yang masa tinggal di pesantren tidak lama, kurang dari setahun dan tidak bercita-cita menjadi 'ulamā' memiliki tujuan untuk mencari pengalaman dalam hal pendalaman perasaan keagamaan. Kebiasaan semacam itu terlebih-lebih dijalani pada waktu bulan Ramadhan. Santri yang bertujuan ingin menjadi ulama mengembangkan keahliannya dalam Bahasa Arab melalui sistem sorogan dalam pengajian sebelum mereka masuk pesantren mengikuti sistem bandongan.

Menurut Dhofier, kitab-kitab yang diajarkan di pesantren dapat digolongkan menjadi delapan kelompok, yaitu naḥwu dan șarāf, fiqh, uṣūl fiqh, Hadis, tafsir, tawhìd, tasawuf/etika, dan cabang lain seperti tarikh dan balāghah. Kitabkitab tersebut berupa teks yang pendek sampai terdiri dari berjilid-jilid. Kitabkitab tersebut dapat dikelompokkan pada tiga kelompok, yaitu kitab dasar, kitab menengah, dan kitab besar. Kesamaan kitab yang diajarkan dan sistem pengajaran menghasilkan homogenitas pandangan hidup, kultural, dan praktikpraktik keagamaan di kalangan santri di berbagai pesantren. Dalam menerapkan sistem pengajaran bandongan dan sorogan, kiai sebagai penerjemah dan sumber informasi ilmu seringkali memberikan pandangan dan penafsiran pribadi atas teks-teks kitab yang dibaca (Hasil Observasi, 2 Agustus 2009). 
Di Pondok Pesantren APIK, kitab-kitab yang diajarkan telah mencakup cabang-cabang ilmu agama, sebagaimana dikemukakan Dhofier. Kitab-kitab ushul fiqh yang diajarkan masih sangat dasar, berbeda dengan kitab-kitab fiqh dan bahasa yang mencapai tingkat kitab besar. Santri dan kiai terlibat kajian mendalam persoalan fiqh menelaah gagasan para penulis klasik, bukan metode berpikirnya. Ilmu metode yang didalami adalah metode bahasa dalam cabang naḥwu dan șarāf. Mereka memperlakukan kitab kuning sebagai sumber ilmu dan kebenaran. Hal yang mereka temukan dalam teks kitab menjadi pengetahuan dan diyakini kebenarannya. Komitmen mereka pada aliran klasik/ tradisional terbangun dari cara mereka memperlakukan kitab kuning dan penjelasan kiai.

Hubungan sistemik santri dan kiai menempatkan kitab kuning sebagai dasar penghubung dan arah hubungan. Kiai senantiasa menjaga tradisi pengajaran klasik dan keberlangsungan pengajian kitab-kitab klasik, sementara santri memiliki cita-cita untuk menjadi penerus aliran klasik tersebut. Kitab kuning menjadi penghubung keduanya. Para santri dan alumni Pondok Pesantren APIK diikat dalam wadah organisasi daerah, untuk membangun sistem keberlanjutan pengajaran kitab klasik di pesantren.

\section{E. Simpulan}

Dalam tradisi pesantren (terutama salaf), bahwa kiai, kitab kuning, dan santri adalah hal yang tidak bisa dipisahkan. Hal ini termasuk juga Pesantren APIK Kaliwungu. Pesantren ini menjaga tradisi pesantren dengan mengajarkan kitab kuning dalam sistem pendidikannya. Uniknya, pesantren ini memodernisasi pembejalaran materi dengan sumber kitab kuning dengan sistem klasikal. Pesantren APIK Kaliwungu mencoba adaptif dengan kemajuan jaman, yang masyarakatnya masih mempertimbangkan aspek formal dalam kehidupan, sehingga APIK juga menerapkan sistem wajib belajar sembilan tahun bagi para santrinya.

Sebagaimana di pesantren pada umumnya, kiai menjadi pusat utama penataan sistem pendidikan dibantu pengurus menjadi pelaksana. Hubungan kiai dan santri adalah hubungan lahir batin. Santri menempatkan kiainya sebagai "murabbi", yang lebih dari sekadar guru semata. Ada ikatan batin dan emosional antara kiai dan santri yang menjadi prasyarat keberhasilan pendidikan kitab kuning di pesantren. 
Nur Fatoni: Kultur Pesantren-Relasi Kiai, Santri, dan Kitab Kuning (hal. 165-177)

\section{Daftar Pustaka}

Dhofier, Zamakhsari. 1982. Tradisi Pesantren. Jakarta: LP3ES.

Dokumen Pondok Pesantren APIK Kaliwungu. 2009. TTP: TP.

Steenbrink, Karel A. 1982. Pesantren, Madrasah, Sekolah. Jakarta: LP3ES.

Suwito NS dan Yusuf, Khoirul Fuad. 2009. Pengembangan Ekonomi Pesantren.

Yogyakarta-Purwokerto: Unggun Religi dan STAIN Press.

Tim Penyusun. 2009. Profile Pondok Pesantren APIK Kaliwungu. TTP: TP. van Bruinessen, Martin. 1994. Kitab Kuning. Bandung: Mizan. 